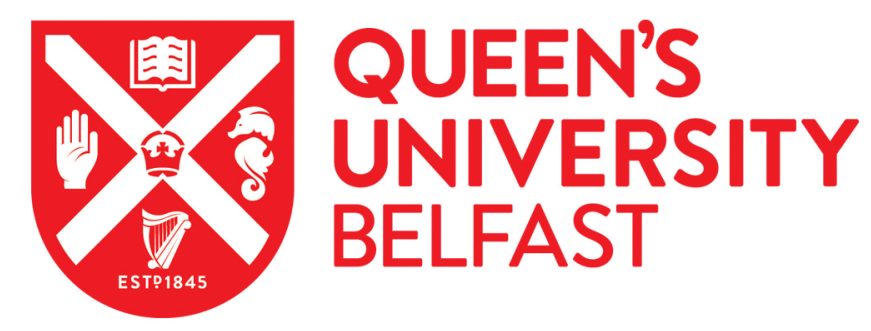

\title{
Planning in and for a post-growth and post-carbon economy
}

Barry, J. (Accepted/In press). Planning in and for a post-growth and post-carbon economy. In R. Cowell (Ed.), Routledge Companion to Environmental Planning and Sustainability. (pp. 120-129). Routledge.

\section{Published in:}

Routledge Companion to Environmental Planning and Sustainability.

\section{Document Version:}

Peer reviewed version

Queen's University Belfast - Research Portal:

Link to publication record in Queen's University Belfast Research Portal

\section{Publisher rights}

Copyright 2019 Routledge. This work is made available online in accordance with the publisher's policies. Please refer to any applicable terms of use of the publisher.

\section{General rights}

Copyright for the publications made accessible via the Queen's University Belfast Research Portal is retained by the author(s) and / or other copyright owners and it is a condition of accessing these publications that users recognise and abide by the legal requirements associated with these rights.

Take down policy

The Research Portal is Queen's institutional repository that provides access to Queen's research output. Every effort has been made to ensure that content in the Research Portal does not infringe any person's rights, or applicable UK laws. If you discover content in the Research Portal that you believe breaches copyright or violates any law, please contact openaccess@qub.ac.uk. 


\title{
Planning in and for a post-growth and post-carbon economy
}

\author{
John Barry
}

Contribution to Cowell, $\mathrm{R}$ et al (eds), Routledge Companion Volume to Environmental Planning and Sustainability

\section{Introduction - the condition our condition is in}

How does the old end and the new begin? How do we identify the point beyond which a practice, idea or objective is no longer beneficial, productive or necessary but have now become the opposite? This the conundrum facing planning in the $21^{\text {st }}$ century, how to decouple societies and economies from fossil fuel energy, but also the role of planning in decoupling societies from an uncritical focus on achieving, facilitating or coordinating the achievement of orthodox 'economic growth'. Planning here is understood mainly as the purposeful, political and public (and ideally democratic) steering of infrastructural and mainly urban development, encompassing, inter alia, land use, spatial planning, energy planning, and includes the achievement of economic, cultural and environmental goals. This chapter mainly discusses planning debates within the UK and Irish contexts. The first question which serves as the starting point of this chapter is to ask if the objective of economic growth is now ecologically unsustainable, socially divisive and has in many countries passed the point when it is adding to human wellbeing? The second is how growth and planning are both currently dependent upon a fossil fuel energy system which, like the growth economy it fuels, is now ecologically unsustainable, socially disruptive, produces multiple problems from ill-health to extractive injustice and the creation of 'sacrifice zones', and ultimately constitutes a risky energy basis for a sustainable economy? Simply put our societies and conventional planning processes are dependent upon (some might say addicted to) GDP measured and endless economic growth and carbon energy, both of which have passed thresholds indicating we need to replace them. Which of course raises the addition question: if we accept or consider the exhaustion of endless growth and our continuing carbon energy dependence, what replaces them? And what is the role for planning in both that transition and the possible purpose of planning in a post-growth and post-carbon context? These are the main concerns of this chapter.

The structure of the chapter is as follows. The first section outlines what is meant by 'economic growth' and identifies some of the main 'pro-growth' bias (and carbon energy dependence) within dominant understandings of planning. These include, inter alia, planning's role in promoting policies and discourses of international competitiveness, the privatisation of public space, support for pro-market urban regeneration, and a view of planning as facilitating market-based economic growth. It then proceeds to discuss some features of 'post-growth' and 'post-carbon' planning. These include the 
central role of planning in any 'just transition' to a low carbon economy; the place of a more pro-active state in that planning process, and the integration of social justice 'floors' and ecological 'ceilings' into any post-carbon, postgrowth planning. The chapter concludes that we need new imaginaries and objectives for planning in the $21^{\text {st }}$ century, for conditions very different from those of post-war and late $20^{\text {th }}$ century. We need view to replace economic growth with notions of prosperity and ideas of planning creating prosperous and flourishing communities where high quality of life is decoupled not just from high carbon use, resource intensity and pollution, but also simplistic and out of date objectives of 'economic growth'.

\section{The pro-growth bias of conventional planning}

A question that is rarely asked in public or political discourse is 'why do we need economic growth?', so self-evident is it that 'we' need 'it'. There is a small 'heterodox' academic political economy tradition critical of growth, including seminal works by Daly (1973) and Georgescu-Roegan (1971) for example (and more recent work by Jackson (2017) and Reardon, Madi and Cato (2018) ) for an overview of this tradition see Barry (2012: 151-154)), and landmark reports such as Limits to Growth (Meadows et al, 1972), and in the wake of the 2007-08 global economic crisis there was a short-lived, but high-level political interest in 'moving beyond GDP' (Stiglitz, Sen and Fitoussi, 2008) to focus on measuring wellbeing. However, this 'post-growth' body of knowledge is marginalised within the academy and receives no serious and sustained public discussion or political advocacy (apart from Green Parties and sections of the environmental movement). Despite climate science indicating we need to question economic growth (Anderson and Bows, 2011), despite growing social psychological research highlighting the negative consequences of growth for human flourishing (Kasser, 2003) and epidemiological and sociological analysis pointing out how growth reproduces and deepens socioeconomic inequality (Wilkinson and Pickett, 2010), economic growth remains a hegemonic 'core state imperative' and 'commonsense' social goal (Barry, 2018). It is economic growth we are told that ensures pensions for when we retire. It is economic growth that creates the wealth we can then use to spend on social or medical infrastructure (such as a national health care system) and welfare payments, or indeed remedial environmental policies. In this way economic growth is a means to these various ends, and in growth-oriented societies policies and practices from education to planning are both shaped to help achieve that end and increasingly judged by their contribution to realising economic growth. What is rarely aired is whether, a) growth really is a means to those ends and has not become an end in itself, b) those ends could be met without economic growth and c) or that there is a threshold beyond which growth is no longer a net positive for societies? 
First, we need to answer the question: what do we mean by 'economic growth'? By economic growth is meant undifferentiated, GDP (Gross Domestic Product) measured growth, as a permanent feature of the economy (Barry, 2018). Simply put GDP is a measure of the 'busyness' of the economy, the monetised measurement of the market value of all final goods and services produced in a period of time (usually measured and commented upon etc. in the media, quarterly and annually). It is best thought of as measuring the financial value and volume of market exchanges. That only market exchanged goods and services are counted has important implications, not least in terms of 'what gets measured' not only 'gets done' but also 'gets recognised'. On the one hand, negative impacts of economic activity such as pollution is not included in GDP, or a whole host of other negative 'externalities' such as ill health, anxiety, stress etc. On the other, activities such as gendered housework or volunteering are excluded, hence GDP only values and recognises 'employment' not 'work' per se.

GDP measured growth is undifferentiated in that it does not distinguish between economic activities and expenditure that many would view as socially negative. So being forced to have a long commute from one's home to place of work or study, due in part to spatial planning decisions and strategies, is a disutility for the individual (and also increases pollution if its carbon-fuelled transportation, especially car-based), this is good for GDP measured economic growth. These 'defensive expenditures' are people spending income (and resources and energy) to protect themselves and their welfare from the unwanted side effects (health, social, economic) of specific productive activities or due to the structure of the economy as whole. In short, people are forced to spend income that does not increase their welfare. But GDP is indifferent and blind to those expenditures: whether its expenditures that add or subtract from welfare, they all add to economic growth. Growth is growth is growth. It is this that leads Mark Anielski to provocatively note that,

"The ideal economic or GDP hero is a chain-smoking terminal cancer patient going through an expensive divorce whose car is totalled in a 20-car pileup, while munching on fast-take-out-food and chatting on a cell phone. All add to GDP growth. The GDP villain is non-smoking, eats home-cooked wholesome meals and cycles to work." (Anielski, 2007: 30)

Related terms and concepts, often found in the company of this growth discourse include 'attracting foreign direct investment', 'promoting free trade', 'competitiveness', 'increasing labour productivity', 'encouraging innovation', 'cultivating entrepreneurship', 'removing red tape and bureaucracy', 'reducing regulation' and so on. All of which are familiar to and woven within recent planning practices and theorising, of what Rydin terms 'growth-dependent planning' (Rydin, 2013). Discussing the British planning experience (though relevant I would argue to most carbon-based, capitalist economies), she states that, "Currently the institutional framework of the planning system embeds 
growth-dependent planning as the only alternative" (2013: 11), and that this dependence upon growth has increasingly shaped the planning profession (ibid.: 15).

The connection between growth and planning is a long one, and can be traced historically, for example, to the 'public health' focus of urban planning in the late $19^{\text {th }}$ and early $20^{\text {th }}$ centuries, to the post-WWII context of economic and urban reconstruction and regeneration and Keynesian welfare state building (Barry, 2018). While there is evidence of planning being concerned with noneconomic and non-growth objectives, such as public health or social inclusion (thus importantly reminding us that there is no necessary as opposed to politically contingent connection), in recent decades under neoliberalism the relationship between planning and growth has become even more accentuated. An illustration of this is that the Royal Town Planning Institute for example has a section on its website entitled 'Planning and Growth' where we are told:

"The RTPI's work programme on the value of planning seeks to promote and inform a more considered, balanced and evidenced debate on the relationship between planning and economic growth. Contrary to the views of some critics, planning can and does play a positive and proactive role in sustainable economic growth and development". (RTPI website; emphasis added).

Then there is also planning's implicit or explicit (and often uncritical) dependence upon conventional, mainstream economic analysis (Rydin, 2013; Healey, 1998; Adams and Tiesdell, 2010). For Rydin, "Behind the paradigm of growth-dependent planning lies a particular view of urban change rooted in neo-classical economics" (Rydin, 2013: 35) in which market actors, most prominently developers, are the key actors. In recent times, even when planning is expressed as achieving the 'triple bottom lines' of the social, economic, environmental dimensions of 'sustainable development', it is the economic that usually dominates. And a narrow, monetised GDP measure of growth at that. A sense of how GDP is not only an inaccurate measure but perverse (and also indicates its concern with capital as opposed to labour) is that 'jobless growth' is viewed as 'good' and positive. Again, growth is growth is growth. As Ellis notes, even where planning policy acknowledges the goal of wellbeing, this "is almost exclusively linked to arguments for economic growth, without really appreciating that the very type of development that prioritises growth, also tends to erode the very basis of healthy urban development" (Ellis, 2016: 3; emphasis added).

Boland (2014) perceptively deconstructs this uncritical pro-growth bias within dominant conceptualisations of planning. He notes in his analysis of 'neoliberal competiveness' and planning's role in promoting and facilitating the international competiveness of cities and city-regions to boost economic 
growth via, inter alia, shape and place making to attract mobile capital and a talented labour force:

"neoliberal competitiveness is a 'postpolitical strategy' and represents a 'dangerous obsession' for spatial planning...[characterised by the] 'prioritisation of economic growth', 'privileging of competitiveness', 'marketisation of planning', and 'speeding up of planning decisions"'. (2014: 770, 773)

While it would be going too far to say that dominant accounts of contemporary planning sacrifice much at the altar of growth, or that political (and democratic) pro-growth planning is not possible, or that other objectives are available to planners, we do have to recognise that growth occupies not only a central but one could say 'constitutive' position within planning. Here we have only to think of the determined and largely successful and ideologically motivated and sustained attack on or framing as planning as the 'dead hand of the regulatory state'. Here not only do we find familiar rightwing/neoliberal tropes of the 'anti-business' and therefore 'anti-growth' character of a certain type of planning, but the internalisation by the planning process itself that its main (or one of its main) roles is to 'facilitate', 'predict and provide' for market-led development, regeneration, housing, spatial development etc.

Part of the logic for prioritising growth above other social, cultural, health or ecological aims (apart from the 'group think' and institutionalisation of growth within planning) is what might be called an 'Achilles lance' justification. Just as the ancient Greek hero had a mythical lance that could heal the wounds it inflicts, likewise with growth there is a belief that it can also heal the various economic, social and ecological damage it causes. And on the face of it there is sound reasoning behind this long-standing assumption. Namely, that the additional wealth, jobs and tax or rates revenue that growth brings can compensate, clean up, ameliorate and otherwise produce (eventually perhaps) 'benefits' that offset its 'costs'. But like growth itself, this tells us nothing about the distribution of the costs and benefits and whether what is lost or damaged can be 'made good' by the economic wealth created. But such is the persuasiveness and 'commonsense' of promoting and aiming for economic growth that whether expressed as a modern form of mythic thinking (Achilles Lance) or more prosaically as you cannot make an omelette without breaking eggs', planning has become a 'pro-growth' discipline and institutionalised process (Rydin, 2013). And the problem with this is not necessarily that planning is pro-growth. Growth can be, and we have the historical evidence that it was, and is, and can be, under a certain set of specific circumstances and conditions, positive, lift people out of poverty, create public goods, enhance human individual and collective wellbeing and so on (Barry, 2012). Hence, the argument here in this chapter should not be read as 'anti-growth', but rather questioning economic growth, as defined above, as a permanent as opposed to a temporary feature of the economy, or growth for growth's sake. 
Economic growth is, and should always be, a means not an end in itself, but sadly this is something forgotten within planning.

\section{Growth and fossil fuels}

There is a strong casual link between carbon energy (fossil fuels such as coal, gas and especially oil) and economic growth. In short, carbon energy is needed for economic growth, and access to cheap, secure, reliable sources of carbon energy is an essential development objective. But this reliance on carbon energy as essential to the 'commonsense' pursuit of growth (viewed as the 'normal' or 'healthy' condition of the economy), and therefore planning in the pursuit or service of growth, is largely un - or under-recognised. But the reality is that the role of energy for planning and the economy goes beyond its necessary as a material input or precondition for urban development, economic activity and the achievement of GDP growth. Fossil fuels, particularly oil, also shape how we think about and conceptualise and understand planning and the economy. Mitchell, for example, makes a persuasive case that the modern 'economy' and the 'economic knowledge' that developed around it in the late 1930s should be viewed as a form of 'petroknowledge' central to which was endless economic growth (Mitchell, 2011). Modern economics therefore, and, by extension planning based either on a growth dependence (Rydin, 2013) and/or neoclassical and neoliberal economics (Boland, 2014) are 'petro-knowledges' in the sense of being oriented around achieving and managing an endlessly growing economy, and economy which depends on cheap and securely available sources of oil.

A key issue to consider is how and what ways the planning system can reinforce as opposed to disrupt and help overcome what Unruh terms 'carbon lock in' (Unruh, 2000). An example of the latter would be the privileging, naturalisation and assumption of increased motorised car mobility in transport and spatial planning. As Driscoll puts it:

"it is overwhelmingly evident at this juncture that radical interventions will be necessary in order to escape carbon lock-in in the transport system. As long as planners treat road, rail and non-motorized transport modes as fungible goods, then it is likely that the existing path dependencies will reinforce and reproduce a high-carbon transport system". (Driscoll, 2014: 318; emphasis added).

Thus in this case planning may have to face head on the unsustainable 'induced demand' that accompanies new road builds, both the increased traffic that results directly from the provision of new infrastructure, and the land-use patterns that are also induced by privileging the private car over other mobility modes. While actively 'demarketing the car' might be beyond the ability of planning alone to achieve (not to say controversial), at the very least overcoming carbon lock in requires planning to continue its uneven evolution beyond an out-dated and unsustainable 'predict and provide' approach. Other examples would include unsustainable and carbon- 
intensive forms of suburbanisation and sprawl, out of town developments etc. and for planning to add another 'post-' to its 'to list', namely 'postsuburbanisation', to add to post-carbon and post-growth (Phelps et al, 2006). But equally if we accept both the causal link between growth and carbon energy (i.e. growth is dependent upon carbon), and arguments around the negative social, economic and environmental impacts of orthodox economic growth (Barry, 2012; Wilkinson and Pickett, 2009), then to that extent planning uncritically promotes an unsustainable 'pro-growth' agenda. And therefore it also 'locks in' not simply an unsustainable but an unjust and inequality producing socio-economic system. After all, it is not just sustainability transitions per se that should concern planning, but its contribution to a 'just transition' away from 'actually existing unsustainability'.

\section{Planning for a Just Transition: Social justice floors and ecological ceilings}

The term 'just transition' has emerged in recent years to conjoin social justice - more specifically, the equitable distribution of the benefits and costs of the transition away from high carbon and unsustainable development trajectories - with the environmental, climate, resource and energy reasons for that transition. Whereas the latter are largely biophysical limits, ceilings or 'planetary boundaries' (Rockstrom et al, 2009) within which human development is sustainable, the former represent the 'social floors' below which individuals and communities are not allowed to fall in terms of livelihoods, flourishing, human rights and basic standards of living (Raworth, 2018). This is what Kate Raworth terms the 'Safe and Just Space for Humanity' (Raworth, 2012), and it captures the context of planning in the $21^{\text {st }}$ century i.e. our climate changed, carbon constrained world.

A key feature of the 'just transition' approach to decarbonisation, climate change and sustainability transitions is the recognition that it is possible to have 'unjust' sustainability transitions. One the one hand this is a possibility if one focuses narrowly on the environmental/ecological aspects (to the neglect of social dimensions, such as justice and equity concerns or procedural issues of democratic decision-making for example). On the other hand, unjust transitions are also possible if one narrowly reduces sustainability transitions to 'greening' the status quo.

In terms of the first possible 'unjust transition' type we can point to authoritarian and inequitable approaches to achieving a transition beyond 'actually existing unsustainability' (Barry, 2012), such as approaches which violate peoples' basic human rights or are indifferent to the unfair distribution of costs of such transitions. Here, countries like China are routinely presented as a real world example of this type of 'unjust transition' (Swilling and Annecke, 2012). However, one could also point to a similar problem $n$ strands of what might be termed 'apocalyptic' environmental discourses 
around climate change, where both the scale and the urgency of the proposed transition mean that since 'survival' (of the species, civilisation, or culture) is the objective, both democracy and justice are superfluous. Since neither democracy nor justice is strictly speaking necessary for survival, and/or integrating them within a sustainability transition will delay or render that 'survival sustainability transition' impossible, we must abandon or 'temporarily' put democracy and claims of justice on hold. Within such a sustainability framing planning for 'bare life' would be akin to a military process of non-market, non-democratic and non-justice sensitive resource allocation, place and space creation. Such planning sadly bears an uncanny resemblance to dominant features of existing planning practice in its technocratic, statist, expert, top-down 'command and control' character (Marshall and Cowell, 2016).

The second form of 'unjust transition' relates to the questionable 'justice' of 'greening business as usual' as dominant approaches to sustainability transitions, such as mainstream 'sustainable development' discourse, 'ecological modernisation' and 'green growth strategies'. Here, the problem is the greening/decarbonisation/dematerialisation and otherwise rendering less unsustainable a capitalist socio-economic order that is structurally unjust and inequitable. But the question here is: do we want a low carbon version of an unjust system? On this point, there is merit in Friends of the Earth Scotland's call for a 'Just Transition Commission' to oversee and develop a strategy for the implementation and review of any managed and orderly sustainability that would ensure, for example, that as far as possible costs are equitably distributed, and those displaced from jobs or settled and valued ways of life are compensated (Crighton, 2017). Such high level state-based (if not statist or 'state-centred') strategies to develop policies aimed at decarbonisation could provide the guidance and democratically agreed objectives and principles enabling planning to contribute and play its part in addressing the possible injustices and negative impacts such a socio-energy transition could generate (Healy and Barry, 2017). And the institutionalisation of a 'just transition' strategy, especially if democratised and participative, opens up the possibilities of objectives beyond orthodox economic growth, such as health or wellbeing for example, emerging to supplement or even replace growth as the main aim of planning.

\section{Bringing the state back in}

A longstanding justification for state/public planning and wider state intervention is on the grounds of coping with market failures and 'externalities', where market activities create social, ecological or intergenerational costs and benefits which are not reflected in the market price of the good or service. For example, climate change has been described as the greatest market failure the world has seen. However, while a 'market failure' argument does offer a common and powerful reason for planning and state intervention in private market behaviour or the structure of the market 
itself, I do wonder about the normative framing of such 'remedial' justifications for planning. That is, such remedial arguments in support of planning are of course premised on the idea that the preferred, superior and default position is for the market to provide goods, services and the infrastructure for good lives and a good society, with the state via planning a secondary, inferior and 'second best' institutional provider. And this ranking and conventional thinking around planning is something that is fundamentally challenged by the socio-ecological crisis where democratic planning rather than free market provisioning is the superior and most effective way to solve problems, allocate resources and create the infrastructure for resilient and sustainable communities and societies. At the same time as there being grounds for a more proactive planning system to cope with (adapt) or deal with the root causes (mitigate) of the negative effects of climate change, there are also justifications for planning in relation to the lack of positive externalities and adequate provision of a variety of public goods. Thus, a planned approach should also ensure the creation and sustaining of public goods, such clean water, air and accessible open spaces and the planetary public good of a stable climate system.

The climate crisis and the need for greater 'carbon control and management' has, and can, provide opportunities and obligations for the state to become 'greener' by becoming more interventionist (and possibly more creative and more democratic) as it steers, coordinates or directly manages society-wide sustainability, energy and economic socio-technical transitions (Ellis et al, 2018). As While et al note the climate crisis has enabled a new state-centred and "distinctive political economy associated with climate mitigation in which discourses of climate change both open up, and necessitate an extension of, state intervention in the spheres of production and consumption" (While et al, 2010: 82; emphasis added). Such "policy or governance opportunity structures' that moments of crises present for state reconfiguration, obviously also provide opportunities for the rethinking and reconfiguration of urban planning. These range, inter alia, from the long-overdue integration of spatial and energy planning (Stoeglehner et al, 2016); viewing 'war time mobilisation' as a model for rapid decarbonisation (Delina, 2016); an explicit commitment by planning to move beyond technological innovation to provide policy support and space for social experiments in new low carbon and post-growth forms of living; to seeing how addressing the carbon and climate crisis can open up of planning to more democratic and democratised institutionalised forms. And democratised planning is understood explicitly not as consensus creation and agreement, but seeing planning decision-making as recognising and welcoming and indeed encouraging agonistic contestation and debate (Barry and Ellis, 2010).

While obvious, it is worth highlighting that this direction of travel for 'just transition' planning requires the (re)politicisation of planning as a necessary precondition for its democratisation, and a decisive movement away from a 
'top-down' and technocratic, expert-driven conceptualisation of planning. And of course recognising that the responsibility for envisioning and implementing any post-carbon, post-growth just transition is not the responsibility of the planning system alone, but it does have a vital role, not least as a key dimension of 'bringing the state back in' as a necessary (if insufficient) institutional component in navigating our pathways to sustainable sociotechnical futures in the coming century.

\section{Conclusion: Planning for post-growth and post-carbon socio-technical futures}

The aim of this short chapter has been to suggest a new purpose for planning in $21^{\text {st }}$ century, one which focuses on human wellbeing and other objectives beyond GDP measured economic growth and associated ideas of competiveness etc., and is also explicitly premised on moving away from a carbon based energy system. But while new in terms of the context of planning in the $21^{\text {st }}$ century viz. climate change, decarbonisation, the 'Anthropocene' and 'post-growth economics', there is also something old in the argument here around planning's role in creating post-growth and postcarbon futures as a return to the 'public purpose' of planning (Bowie, 2016). It also proposes a creative and what might be termed 'realistically utopian' form of planning. As the ancient wisdom contained in books such as the Bible tell us that 'without vision the people perish', or more modern versions such as research on socio-technical sustainability transitions say much the same in terms of the importance of an agreed and co-created and shared 'transition vision', we need to ask what is the vision of and for planning in a carbon constrained, climate changed world? As Briel puts it "Creating visions of a post-carbon urban future can help generate a positive image of the transformed city in which urban life quality, economic and social vibrancy improve for citizens, while carbon emissions decrease" (2016: 1).

There is both a responsibility on the discipline/interdiscipline of planning, (including professional planning training and practice), and an exciting opportunity for planning to contribute to the transition to post-carbon and post-growth urban futures. This is especially in relation to the provisioning and governance of space and energy, the intersection of infrastructure, space, place and the materialities of low-carbon transformations across sociotechnical networks at different scales. Here as well as place making, planning has a part to play in 'just transitions' towards and experiments in new sociotechnical modernities, of what Ellis terms "new visions of future urban living" (Ellis, 2016: 2). At the very least there are grounds for planning to go beyond and supplement aiming for growth with other aims such as a health-led planning system, as well as for planning to help overcome 'carbon lock in'. Or for planning to focus on prosperity with the aims of creating "sustainable and prosperous communities...understood as places that support people to flourish and thrive in diverse ways that go far beyond orthodox prosperity as wealth creation and economic growth" (Woodcraft and Smith, 2018: 72). 
Hence, planning in the $21^{\text {st }}$ century should be oriented around the following: how to design urban forms that produce high levels of human wellbeing and flourishing while using less energy and resources, and where growth is a potential by-product, not the goal of planning. And the reality is the sooner policies change to prepare communities, cities and our built 'commons' for a decarbonised and post-growth future, the more effective (and cheaper) that transition will be. After all, it is wise to fix the roof when it is sunny, not when it is raining.

\section{Further reading}

For accounts of the relationship between planning and economic growth Rydin's 2013 book, The Future of Planning is a good place to start, while the articles by Boland and Ellis in the references unpack some of the specifically neoliberal dimensions of this relationship. On planning, climate change and energy see Bulkeley et al (eds), (2010) Cities and Low Carbon Transitions, (London: Routledge). On low carbon and just transitions see Leech et al (eds), The Politics of Green Transformations (London: Routledge) and the Healy and Barry article below.

\section{References}

Adams, D. and Tiesdell, S. (2010), 'Planners as Market Actors: Rethinking State-Market Relations in Land Property', Planning Theory and Practice, 11:2; 187-2-7.

Anderson, K. and Bows, A. (2011), 'Beyond 'Dangerous' Climate Change: Emission Scenarios for a New World', Philosophical Transactions of the Royal Society A, 369, 20-44

Anielski, M. (2007), The Economics of Happiness: Building Genuine Wealth (Gabriola Island: New Society Publishers).

Barry, J. (2018), 'From Pre-Analytic Axiom to 'Core State Imperative' and Dominant 'Commonsense': A Genealogy of the Ideology of Economic Growth' under review with New Political Economy.

Barry, J. and Ellis, G. (2010), 'Beyond consensus? Agonism, contestation, republicanism and a low carbon future', in Devine-Wright, P. (ed.), Renewable Energy and the Public: From NIMBY to participation, (London: Earthscan), 2942.

Boland, P. (2014), The Relationship between Spatial Planning and Economic Competitiveness: The 'Path to Economic Nirvana' or a 'Dangerous Obsession'?', Environment and Planning A, 46:4; 770-787.

Bowie, D, (2016), The Radical and Socialist Tradition in British Planning: From Puritan Colonies to Garden Cities (London: Routledge).

Briel, M. (2016), Visions for Post-Carbon Urban Futures: Why They Are Useful and How to Create Them, POCACITO Policy Brief No. 2, available at: 
https:/ / pocacito.eu/sites/default/files/POCACITO_PolicyBrief_No2_Visions_for_low_carbon_cities.pdf (accessed 16/5/18)

Brock, T. and Crick, J. (2013), 'The Politics of City Building: Pro-Growth Planning Regimes and Equitable Distribution of Infrastructure', Carolina Planning Journal, 38: 1; 17-24.

Crighton, M. (2017), 'Planning for a Just Transition has to be part of Scotland's Climate Strategy', available at: https://foe.scot/just-transitionscotland-climate-strategy/ (accessed 16/5/18).

Daly, H. (ed), (1973), Toward a Steady-state Economy, (San Francisco: W.H. Freeman)

Delina, L. (2016), Strategies for Rapid Climate Mitigation: Wartime Mobilisation as a Model for Action?, (London: Routledge).

Driscoll, P. (2014), 'Breaking Carbon Lock-In: Path Dependencies in LargeScale Transportation Infrastructure Projects', Planning Practice and Research, 29:3, 317-330

Ellis, G. (2016), 'Using the Planning System to Secure Health and Well-being Benefits', Northern Ireland Assembly, Knowledge and Exchange Seminar Series Briefing, available at:

http://www.niassembly.gov.uk/globalassets/documents/raise/knowledge_e xchange/briefing_papers/series5/geraint-ellis-kess-breifing-june-2016.pdf (accessed 16/5/18).

Ellis, G., Hume, T., Barry, J. and Curry, R. (2018), Catalysing and Characterising Transition Synthesis Report, (Belfast: Queen's University, Belfast).

Georgescu-Roegen, N. (1971), The Entropy Law and the Economic Process, (Cambridge, Massachusetts: Harvard University Press).

Healey, P. (1998). 'Building Institutional Capacity through Collaborative Approaches to Urban Planning, Environment and Planning A, 30:9; 15311546.

Healy N. and Barry J. (2017), 'Politicizing Energy Justice and Energy System Transitions: Fossil Fuel Divestment and a "Just Transition"', Energy Policy, 108: 451-459.

Jackson, T. (2017), Prosperity without Growth: Foundations for the Economy of Tomorrow, (London: Routledge).

Kasser, T. (2003), The High Price of Materialism, (Cambridge, MA: MIT Press).

Laarman, J. (1996), 'Planning for Forest Use and Conservation: Guidelines for Improvement', (Rome: Food and Agricultural Organization of the United Nations), available at: 
http://www.fao.org/docrep/w8961e/w8961e06.htm\#TopOfPage (accessed $16 / 5 / 18)$.

Marshall T and Cowell R (2016) 'Infrastructure, planning and the command of time', Environment and Planning C: Government and Policy, 34:8, 18431866

Meadows, D., Meadows, D. and Randers, J. (1972), The Limits to Growth: A Report for the Club of Rome's Project on the Predicament of Mankind, (New York: Universe).

Parker, G. and Doak, J. (2012), 'Competitiveness', in Key Concepts in Planning (London: Sage), 206-216.

Phelps, N., Parsons, N. and Ballas, D. (2006), Post-Suburban Europe: Planning and Politics at the Margins of Europe's Cities (London: Palgrave).

Raworth, K. (2012), A Safe and Just Space for Humanity, (Oxford: Oxfam), available at: https://www.oxfam.org/sites/www.oxfam.org/files/dp-a-safeand-just-space-for-humanity-130212-en.pdf (accessed 16/5/18)

Reardon, J. Madi, A. and Cato, M. (2018), Introducing a New Economics: Pluralist, Sustainable and Progressive, (London: Pluto Press).

RTPI (n.d.), 'The Value of Planning', available here: http:/ /www.rtpi.org.uk/valueofplanning (accessed 26/5/18)

Rydin, Y. (2013), The Future of Planning: Beyond Growth Dependence (Bristol: Policy Press).

Stiglitz, J., Sen, A. and Fitoussi, J-P. (2008), Report by the Commission on the Measurement of Economic Performance and Social Progress,

available

at:http://ec.europa.eu/eurostat/documents/118025/118123/Fitoussi+Co

mmission+report (accessed 12/06/2018)

Stoeglehner, G., Neugebauer, G., Erker, S., Narodoslawsky, M. (2016), Integrated Spatial and Energy Planning: Supporting Climate Protection and the Energy Turn with Means of Spatial Planning, (London: Springer).

Swilling, M. and Annecke, E. (2012), Just Transitions: Explorations of Sustainability in an Unfair World, (Claremont, South Africa: UCT Press).

United Nations Department of Economic and Social Affairs (2014), World Urbanization Prospects, (New York: United Nations).

Unruh G. (2000) 'Understanding Carbon Lock-in', Energy Policy, 28:12; 817830

While A., Jonas A.E. and Gibbs D. (2010), 'From Sustainable Development to Carbon Control: Eco $\square$ state Restructuring and the Politics of Urban and 
Regional Development', Transactions of the Institute of British Geographers, 35: $1 ; 76-93$.

Wilkinson, R. and Pickett, K. (2010), The Spirit Level: Why More Equal Societies almost always do Better, (London: Penguin)

Woodcraft, S. and Smith, C. (2018), "From the "Sustainable Community" to Prosperous People and Places: Inclusive Change in the Built Environment', in Dixon, T., Connaughton, J. Green, S. (eds), Sustainable Futures in the Built Environment to 2050, (Oxford: Wiley). 